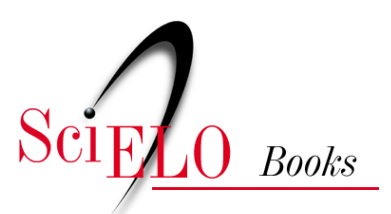

\title{
Reflexões \\ Liberdade na web: juntem-se nós!
}

\author{
Nelson De Luca Pretto
}

PRETTO, N.D.L. Liberdade na web: juntem-se nós! In: Educações, culturas e hackers: escritos e reflexões [online]. Salvador: EDUFBA, 2017, pp. 113-114. ISBN: 978-85-232-2019-8.

https://doi.org/10.7476/9788523220198.0017.

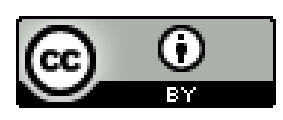

All the contents of this work, except where otherwise noted, is licensed under a Creative Commons Attribution $\underline{4.0 \text { International license. }}$

Todo o conteúdo deste trabalho, exceto quando houver ressalva, é publicado sob a licença $\underline{\text { Creative Commons }}$ Atribição 4.0.

Todo el contenido de esta obra, excepto donde se indique lo contrario, está bajo licencia de la licencia $\underline{\text { Creative }}$ Commons Reconocimento 4.0. 


\section{Liberdade na web: juntem-se nós!}

Inevitável retomar o tema do suicídio do jovem Aaron Swartz, de 26 anos. Nasceu escorpião em Chicago (Estados Unidos), em 1986 e, com 14 anos, falava de igual para igual com cientistas, acadêmicos e hackers da computação e da política, de todos os cantos do planeta.

Aaron desenvolveu um útil sistema para o mundo da informação online que é o Really Simple Syndication (RSS), espécie de dialeto que permite juntar em uma única página web todas as notícias do seu interesse, sem demandar a procura nos seus locais originais. Criou também o Reddit ${ }^{9}$, outra ideia genial: um site para se postar notícias, onde os usuários - nós, os leitores - votamos naquelas que achamos mais importantes, montando, com isso, o que seria a primeira página de um jornal.

Ele criou muitas outras coisas, mas, antes de tudo, era um ativista em defesa da livre circulação do conhecimento. Certo dia estava no prédio do MIT em Massachusetts (EUA) e, com seu notebook, ele criou um script que lhe possibilitava baixar automaticamente cerca de 4,8 milhões de artigos acadêmicos do site JSTOR (um agregador de editoras que vende revistas acadêmicas; uma espécie de intermediário dos intermediários da produção científica, as editoras. É com essas empresas que a CAPES/MEC negocia para manter o importante Portal de Periódicos, que custa aos cofres públicos brasileiros cerca de 65 milhões de dólares anuais).

Pois Aaron, dizem, nem distribuiu os textos. Mesmo assim, foi processado e, se condenado, teria que pagar multa de um milhão de dólares e 35 anos de prisão. Depressivo, não aguentou a barra! Deu fim à própria vida para que nós continuássemos ativos na luta pela liberdade de circulação do conhecimento.

Desde a sua morte em 11 de janeiro de 2013, foram muitos os escritos sobre sua curta vida e sua radical atitude. Mais do que isso, tem sido oportunidade para se refletir sobre a necessária defesa das liberdades na web.

\footnotetext{
${ }^{9}$ https://www.reddit.com/
} 
No caso brasileiro, representa mais uma chance para intensificarmos a pressão sobre os nossos deputados federais para que não continuem, no afogadilho, aprovando leis isoladas que tipificam crimes na internet, sem antes aprovar o seu Marco Civil, garantia dos direitos do cidadão na web. Quando pautada, a votação tem sido sistematicamente adiada em função de um poderoso lobby contrário à internet livre e em defesa dos interesses das grandes corporações.

Em 2008, Arron Swartz lançou o Manifesto Guerrilha, um testamento em defesa da livre circulação da informação científica, exaustivamente citado nos últimos dias. Para ele, "se somarmos muitos de nós, não vamos apenas enviar uma forte mensagem de oposição à privatização do conhecimento - vamos transformar essa privatização em algo do passado."

O Manifesto termina com a conclamação: "Você vai se juntar a nós?". Vamos, diremos em alto e bom som!

Publicado no jornal Correio ${ }^{*}$, Salvador, em 28 de janeiro de 2013.

\section{Liberdade para a internet (e para tudo!)}

No mês passado (junho de 2015), escrevi sobre os movimentos abertos, com destaque para a Ciência Aberta. Foi uma primeira provocação para abrir o mês de julho, pois já sabia que, ao longo do mês, teríamos um conjunto de atividades que retomariam o tema, direta ou indiretamente. Aqui da Bahia, comemoramos o Dois de Julho, data da sua Independência (e do Brasil), dia comemorado pelos baianos com muita festa, euforia, participação popular e, claro, com muita reivindicação política. Nessa data, em 1823, os baianos expulsaram os portugueses, declarando a independência da Bahia, com isso consolidando a independência do Brasil. O Dois de 